\title{
De andres stemmer
}

Fjermeros $\mathrm{H}$.

Åndssvak!

Et bidrag til sentralinstitusjonens og

åndssvakeomsorgens historie. 334 s, ill. Oslo:

Universitetsforlaget, 2009. Pris NOK 349

ISBN 978-82-15-01362-6

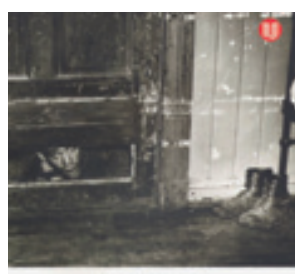

Få grupper er i den grad stigmatisert med betegnelsen «de andre» som dem norsk åndssvakehistorie forteller om. I 1990årene gjorde verANDSSVAK! nepleieren og journalisten Halvor Fjermeros en genistrek: Han intervjuet dem han

kaller innsatte og ansatte i denne omsorgen. Han lot menneskene som ikke blir spurt komme til orde. Det er en underdrivelse når han skriver at hverdagslivet på institusjonen blir borte i beretninger om sentralinstitusjonens vekst og fall og at «kunnskapen om dette livet, slik det fortonte seg i mellomkrigstida og de første årene etter den andre verdenskrig, er i ferd med å forsvinne». Mange av intervjuene ble foretatt i siste liten. De alene gjør at dette er en viktig bok. Det er i kraft av dem at dette bør bli et standardverk.

\section{Personlige historier}

Fjermeros kjenner Emma Hjorths Hjem og de menneskene som levde der fra innsiden. Han kom dit som pleiemedhjelper i 1971, 20 år gammel, og ble boende der i nesten 30 år, også etter at han hadde skiftet arbeidsfelt

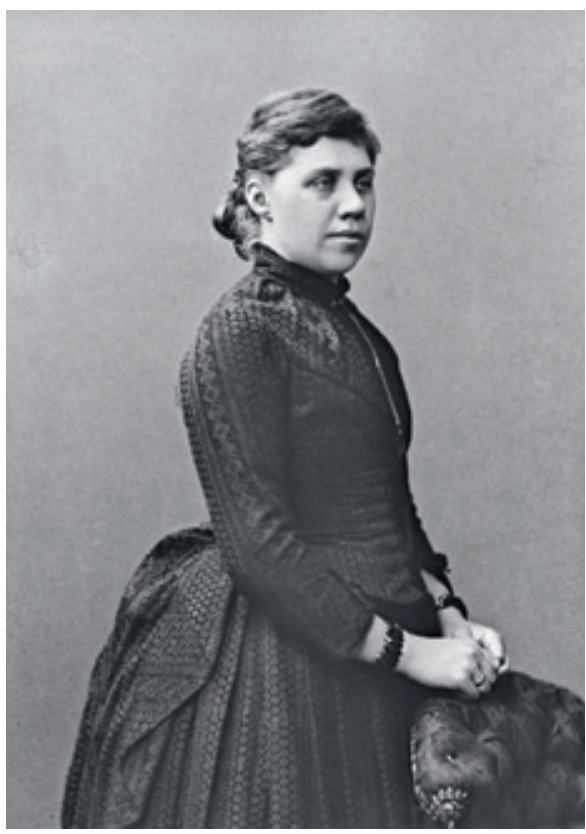

til journalistikken. Han opplevde sentralinstitusjonen på sitt største og de endringer som skjedde gjennom disse årene. Ved 100årsjubileet i $1998 \mathrm{kom}$ hans beretning om hjemmet (1).

I årets utgivelse er perspektivet utvidet, men Emma Hjorths Hjem står sentralt, og historiene derfra ville neppe ha kommet uten Fjermeros' kjennskap til og vennskap med dem som forteller og hans respekt for dem.

Beretningen ville ha manglet uhyre viktige fasetter hvis forfatteren ikke hadde fătt samlet de personlige historiene - et stykke viktig norgeshistorie som så å si aldri nevnes ville ha gått tapt. Den tiden da «de gale» ble utplassert i fjøs og uthus er ikke fjernere enn at en mann født i 1937 kunne fortelle om den. Historiene tegner bildet av et klassesamfunn, offentlig fattigdom og manglende interesse, forakt og sløvhet. Bildet blir skarpere og mer fasettert enn det utredninger, andre offentlige dokumenter og statistikk kan gi.

\section{Munch og Hole}

Ole Bull Munch (1905-96) var stedets direktør og overlege i nesten 30 år (1946-75).

Bildet av ham tegnes ved hjelp av pasienter, pleiere, kjøkkenhjelper og ansatte i hjelpe- og behandlingsapparatet, men også via de grundige kildestudier som i store deler preger Fjermeros' verk. Det er et bevegende og sammensatt portrett. Man får ikke under lesingen det innfall at dette var en kollega man gjerne skulle hatt som sjef, men man får et bilde av en lege som helhjertet gikk inn for å bedre livsvilkårene til dem han hadde ansvar for. Skildringen av hans strid med helsedirektør Karl Evang (1902-81) er en av perlene. Det var Evang som i hui og hast etter krigen fikk ansatt Munch - leger skulle inn i åndssvakeomsorgen. I 1966 sto det en bitter strid om budsjettoverskridelser, egenrådighet fra Munch og en form for allmenn opplysning som verken Evang eller Rådet for legeetikk kunne godta. Det siste gjaldt et fotografi av Munch og en kvinnelig pasient uten klær trykt i bildebladet Aktuell.

Et annet bilde som tegnes ved en blanding av erindringer og et 65 år gammelt intervju er det av diakonen Jens Hole, som ledet institusjonen før Munch (1915-46). Hans forstanderperiode hadde flere mørke sider, men det han bør huskes for er en uttalelse i et intervju med den nazikontrollerte lokalavisen Asker og Bærums Budstikke fra 18. januar 1944. Journalisten spør (et ekko fra naziideologien) om det ikke ville være mest humant å «fjerne slike individer som er uten sjangse for helbredelse og som fører et liv som ofte nærmer seg dyrenes». Hole svarer: «Jeg har sett mange eksempler på at den høyere makt ikke har glemt dem. Og jeg mener at den som har gitt menneskene livet også får ta det. Vi mennesker skal ikke blande oss bort i det.»

Et samfunn skal vurderes etter hvordan de svakeste grupper blir behandlet, og åndssvakeomsorgen setter utviklingen av norsk sosialomsorg i et grelt lys. «Utevern» lyder som et honnørord, men kapitlet om det private utevernet har Fjermeros gitt tittelen Sentralinstitusjonens satellitter, plageåndenes paradis. Diskusjonen om forholdet mellom privat og offentlig behandling og pleie, mellom veldedighet og offentlig ansvar, er ikke ny. Temaet har lange røtter.

\section{For mange sidestier}

Det brede landskap Fjermeros viser oss, tjener Åndssvak! for det meste på. Men ikke hele veien. Fremstillingen settes i perspektiv ved at han trekker inn andre institusjoner og gir et bredere bilde av sosialomsorgen. Han vil mye med denne utgivelsen, av og til for mye. Behandlingen av eugenikk, nazimedisin, eutanasi, steriliseringspraksis i Norge blir stedvis for omfattende, men ikke omfattende nok. Det ville etter min mening gjort teksten bedre hvis deler av dette hadde vært strammere behandlet. Det blir for mange sidestier av noe som godt kunne vært hovedveier. Men da hadde temaene hver for seg fortjent bredere og bedre behandling.

Halvor Fjermeros har skrevet en viktig og nødvendig bok som fortjener lesere med interesse ikke bare for norsk sosialhistorie og medisin, men for norsk historie i sin alminnelighet.

\section{Per E. Børdahl \\ Kvinneklinikken \\ Haukeland universitetssykehus \\ Litteratur \\ 1. Børdahl PE. En viktig del av psykiatriens historie. Anmeldelse av: Fjermeros H. Om hundre år er all- ting glemt? Emma Hjorths historie 1898-1998. Tidsskr Nor Lægeforen 2000; 120: 1230-1.}

